\title{
Analiza odległych następstw po radioterapii radykalnej frakcjonowanej konwencjonalnie i schematem przyspieszonym u chorych na płaskonabłonkowego raka krtani w stopniu T1-T3NOMO
}

\author{
Zbigniew Szutkowski ${ }^{1}$, Andrzej Kawecki ${ }^{2}$, Andrzej Jarząbski ${ }^{2}$
}

Cel pracy. Przeprowadzenie analizy wczesnej i późnej toksyczności zależnej od konwencjonalnie frakcjonowanego (CF) i przyspieszonego napromieniania (AF) u chorych na płaskonabłonkowego raka krtani w stopniu zaawansowania T1-T3N0 leczonych z założeniem radykalnym.

Materiał i metoda. Do analizy włączono chorych leczonych w Centrum Onkologii w Warszawie w ramach wieloośrodkowego badania klinicznego III fazy w latach 1995-1998. Chorych napromieniano Co-60 i w ramieniu CF podawano dawkę 66 Gy w 33 frakcjach przez 45 dni leczenia, a w ramieniu AF skrócono czas leczenia o 7 dni przy zachowaniu pozostałych parametrów.

Wyniki. Wyższe odsetki ostrych odczynów popromiennych obserwowano u chorych poddanych radioterapii przyspieszonej. Odczyny wczesne ustępowały w czasie od 5 do 8 tygodni po zakończeniu niezależnie od zastosowanego schematu frakcjonowania dawki. Nie stwierdzono poważnych późnych odczynów popromiennych w obu badanych grupach chorych.

Long-term late toxicity analysis in patients with stage T1-T3NO squamous cell laryngeal carcinoma treated with radical intent with conventional and accelerated schedules of radiotherapy

Aim of the study. The analysis of early and late toxicity was assessed comparing two schedules of irradiation - conventional fractionation (CF) and accelerated fractionation (AF). Our population of patients had squamous cell carcinoma of the larynx stage T1-T3NOM0. All were treated with radical intent.

Material and method. Patients treated 1995-1998 in the Centre of Oncology in Warsaw were separately analyzed in a phase III multicentre clinical trial. Patients were irradiated with Co-60, in the CF arm to a total dose of 66 Gy in 33 fractions with an overall treatment time of 45 days. In the AF arm the overall treatment time was 7 days shorter but the rest of parameters were not changed.

Results. A higher percentage of acute post-irradiation reactions was observed in patients who underwent AF. The early reactions settled down after termination in 5 to 8 weeks in both fractionation methods. There were no serious late post-irradiation complications stated in both group of patients examined.

Słowa kluczowe: rak krtani, radykalna przyspieszona radioterapia, odczyny popromienne wczesne i późne Key words: larynx cancer, radical accelerated fractionation, early and late reaction 


\section{Wstęp}

Jedną z podstawowych metod zwiększania skuteczności radioterapii jest stosowanie niekonwencjonalnego frakcjonowania dawki przy zachowaniu akceptowalnej toksyczności zależnej od leczenia, zarówno wczesnej, jak i późnej. Dane radiobiologiczne jednoznacznie wskazują, że w trakcie frakcjonowanego napromieniania dochodzi do przyspieszonej repopulacji komórek klonogennych nowotworu. Niekorzystny wpływ tego zjawiska może być rekompensowany poprzez skrócenie całkowitego czasu leczenia, z podaniem całkowitej dawki napromieniania zbliżonej do stosowanej w trakcie napromieniania frakcjonowaniem konwencjonalnym [1-5]. Przyspieszone frakcjonowanie (AF - accelerated fractionation) zwykle zakłada podanie podobnej dawki w czasie skróconym o 1-2 tygodnie w stosunku do frakcjonowania konwencjonalnego (CF - conventional fractionation). Skrócenie całkowitego czasu leczenia można uzyskać poprzez zastosowanie wyższej skumulowanej dawki tygodniowej, podając 6 lub 7 frakcji w tygodniu [6-12].

Dotychczasowe badania dotyczące niekonwencjonalnego frakcjonowania dawki u chorych na płaskonabłonkowe raki narządów głowy i szyi wskazują na poprawę wyleczalności miejscowej i regionalnej oraz przeżycia bez objawów nowotworu. Korzystny wpływ na przeżycia całkowite został wykazany w nielicznych badaniach [9, 13-15]. Również w metaanalizie poprawa w zakresie przeżycia całkowitego okazała się mniejsza w porównaniu z obserwowaną po stosowaniu jednoczesnej chemioradioterapii, co przesądziło o tym, że to ta druga metoda stała się standardowym leczeniem chorych na zaawansowanego raka narządów głowy i szyi. Wyniki przeprowadzonego w Polsce badania III fazy KBN 0295 wskazują jednak, że schematy umiarkowanie przyspieszonej radioterapii mogą być użyteczne u chorych na raka krtani we wczesnych stopniach klinicznego zaawansowania. Krytyczne znaczenie ma tolerancja leczenia. Zastosowanie przyspieszonego napromieniania wiąże się z oczekiwanym nasileniem odczynów popromiennych, przede wszystkim wczesnych, ale również późnych. Zjawisko to może przyczyniać się do zredukowania poprawy indeksu terapeutycznego. Przeprowadzona poniżej analiza wczesnych i odległych następstw przyspieszonej radioterapii, oparta na bardzo długim czasie obserwacji, ma na celu obiektywną ocenę zagrożeń wiążących się ze stosowaniem tej metody.

\section{Materiał}

Przedstawioną analizę przeprowadzono w oparciu o część materiału klinicznego z wieloośrodkowego randomizowanego badania klinicznego III fazy KBN 0295, w której długotrwałe obserwacje po leczeniu były dobrze udokumentowane i prowadzone przez ten sam zespół.

Do analizy włączono 217 spośród 395 uczestników wieloośrodkowego randomizowanego badania klinicznego III fazy KBN 0295, w którym porównywano dwa schematy radykalnej
Tabela I. Charakterystyka materiału klinicznego z uwzględnieniem dwuramiennej randomizacji według typu frakcjonowania dawki napromieniania

\begin{tabular}{lcc}
\hline Cechy & \multicolumn{2}{c}{ Liczebność grup } \\
\cline { 2 - 3 } & $\begin{array}{c}\text { RT konwencjonalna (CF) } \\
(\mathbf{n}=110)\end{array}$ & $\begin{array}{c}\text { RT przyspieszona (AF) } \\
(\mathbf{n}=107)\end{array}$ \\
\hline$\leq 55$ & $42-38 \%$ & $38-36 \%$ \\
$>55$ & $68-62 \%$ & $69-64 \%$ \\
Głośnia & $76-69 \%$ & $71-66 \%$ \\
Nadgłośnia & $34-31 \%$ & $36-34 \%$ \\
Kobiety & $16-15 \%$ & $15-14 \%$ \\
Mężczyźni & $94-85 \%$ & $92-86 \%$ \\
0 & $102-93 \%$ & $101-94 \%$ \\
1 & $8-7 \%$ & $6-6 \%$ \\
T1 & $31-28 \%$ & $39-37 \%$ \\
T2 & $59-54 \%$ & $55-51 \%$ \\
T3 & $20-18 \%$ & $13-12 \%$ \\
\hline
\end{tabular}

radioterapii (frakcjonowanie przyspieszone i frakcjonowanie konwencjonalne u chorych na płaskonabłonkowego raka krtani w stopniu zaawansowania T1-T3N0 [12]. Włączeni do przedstawianej analizy chorzy leczeni byli w Centrum Onkologii wWarszawie w latach 1995-1998. Charakterystykę materiału klinicznego przedstawia tabela I.

\section{Metoda}

Jednym z podstawowych celów badania KBN 0295 było porównanie skuteczności napromieniania przyspieszonego (czas leczenia wynosił 38 dni i był o jeden tydzień krótszy niż w ramieniu kontrolnym) oraz konwencjonalnie frakcjonowanej radioterapii (czas leczenia wynosił $45 \mathrm{dni}$ ). Chorzy byli napromieniani Co-60 w standardowej pozycji terapeutycznej na plecach. W celu unieruchomienia głowy i szyi stosowano maski termoplastyczne. Napromienianie planowano przy użyciu systemu Mevaplan i seryjnych obrazów tomografii komputerowej (TK). Podczas symulacji zasadniczej, zgodnej z planem leczenia, wykonywano zdjęcia weryfikacyjne pól wlotowych. W części przypadków stosowano osłony indywidualne.

W przypadkach raka głośni w stopniu T1 i T2 objętość napromieniana ograniczała się do struktur anatomcznych krtani i nie napromieniano układu chłonnego szyi. Natomiast w przypadkach T3 raka głośni i raka nadgłośni leczenie było dwuetapowe. W pierwszym etapie napromieniano ognisko pierwotne i elektywnie regionalne węzły chłonne szyi do dawki 46 Gy. Następnie, w drugim etapie, napromieniano wyłącznie ognisko pierwotne $z$ marginesem do łącznej dawki 66 Gy, natomiast rdzeń kręgowy pozostawał poza obszarem napromienianym. W przypadku raka głośni T3 i we wszystkich przypadkach raka nadgłośni napromieniano węzły chłonne szyi nadobojczykowe i górnego przedniego 
śródpiersia, stosując pojedyncze pole na wprost. Wartość dawek frakcyjnej i całkowitej wyznaczano i normalizowano w wybranym punkcie referencyjnym, przyjmując — zgodnie z protokołem ICRU-50 [16] - dopuszczalny $\pm 3,5$-procentowy zakres wartości dawki całkowitej w stosunku do dawki referencyjnej.W celu sprawdzenia poprawności leczenia wykonywano weryfikacyjne zdjęcia wszystkich napromienianych pól.

\section{Wyniki}

Odsetek pięcioletniego przeżycia bez wznowy miejscowej u chorych poddanych radioterapii przyspieszonej był o $14 \%$ wyższy w stosunku do obserwowanego w grupie frakcjonowania konwencjonalnego. W zakresie pięcioletniego przeżycia bez objawów nowotworu zysk terapeutyczny przekraczał 15\% [17].

Innym ważnym parametrem podlegającym ocenie była wczesna i późna toksyczność napromieniania. Nasilenie i przebieg wczesnych odczynów popromiennych szczegółowo zostały przedstawione w rozprawie habilitacyjnej pierwszego autora pracy [17].

Wczesne i późne odczyny popromienne oceniano, stosując uproszczoną skalę wzorowaną na skali wg Dische'a [18]. Wczesne odczyny popromienne oceniano systematycznie w trakcie cotygodniowych badań laryngologicznych, a następnie po upływie czterech i ośmiu tygodni od zakończenia radioterapii.

W trakcie regularnych badań kontrolnych po zakończeniu leczenia rejestrowano ujawnione odczyny późne. Znamienność w zakresie stwierdzonych różnic w wynikach leczenia i częstości występowania nasilonych odczynów wczesnych i późnych analizowano przy użyciu testu niezależności $\chi^{2}$, testu $\chi^{2}$ dla trendu we wskaźnikach struktury oraz testu dokładności Fishera.

Ponadto w analizie dotyczącej odczynów późnych wykorzystano estymator Kaplana-Meiera i tzw. „model mieszany".

\section{Odczyny popromienne}

Przeprowadzona w czasie trwania radioterapii ocena przebiegu odczynów popromiennych nie wykazała istotnych statystycznie różnic w powstawaniu i ewolucji reakcji popromiennych pomiędzy dwoma ramionami badania, chociaż u chorych leczonych metodą przyspieszoną występowały one wcześniej i miały nieco większe nasilenie.

\section{Ostre odczyny popromienne}

\section{Ostry odczyn popromienny błon śluzowych}

Toksyczność wczesną poddano szczegółowej analizie i była ona, jak wspomniano, przedmiotem wcześniejszej publikacji, jednak ze względu na ograniczony zasięg pracy habilitacyjnej przedstawiono tę problematykę w niniejszym artykule $\mathrm{w}$ formie skróconej.

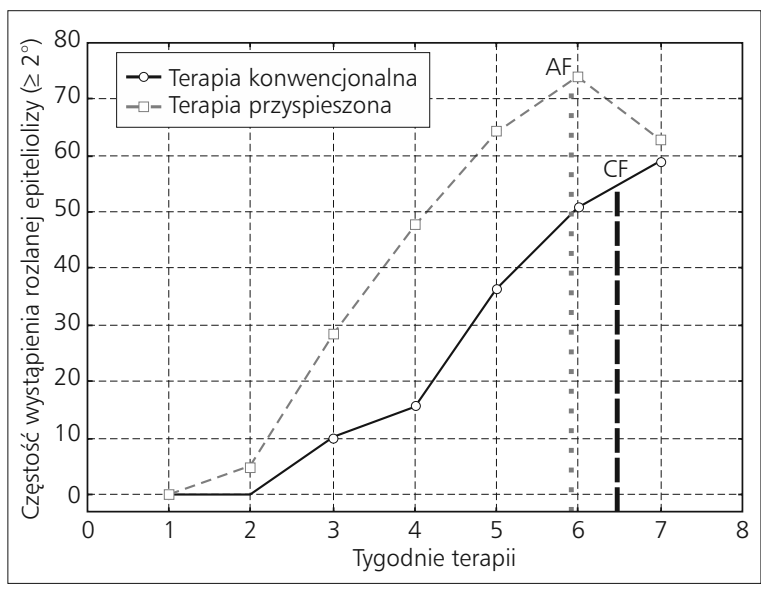

Rycina 1. Dynamika i częstość ujawnienia silnego odczynu popromiennego $\left(\geq 2^{\circ}\right.$ ) błon śluzowych w zależności od frakcjonowania dawki napromieniania (linie pionowe oznaczają czas zakończenia radioterapii w grupie $\mathrm{AF}$ i CF)

Ostry nasilony odczyn błon śluzowych $\left(\geq 2^{\circ}\right)$ o typie rozlanej epiteliolizy ujawnił się wcześniej i występował częściej w grupie AF niż CF (ryc. 1). Pomimo różnic w tempie narastania nasilenia odczynu w obu grupach przebieg i tempo odnowy i gojenia śluzówki były w 8 tygodniu po leczeniu porównywalne w obu grupach: AF i CF (96\% vs 98\%). Nie stwierdzono również istotnej różnicy w nasileniu i zachowaniu odczynów skórnych i w 8 tygodniu po zakończeniu radioterapii prawie u wszystkich chorych w obu grupach doszło do pełnego wygojenia tych odczynów.

\section{Dysfagia}

Trudności w przełykaniu $\left(>2^{\circ}\right.$ ) zaczynały narastać w drugim tygodniu napromieniania i występowały około dwukrotnie częściej u chorych z grupy AF niż CF (rycina 2 — tylko w wersji elektronicznej artykułu).

\section{Bóle przy przełykaniu}

Bóle towarzyszyły trudnościom w przełykaniu i ulegały nasileniu $\left(>2^{\circ}\right.$ ) od 3 tygodnia leczenia, występując przez kolejne tygodnie prawie dwukrotnie częściej w grupie AF niż CF (rycina 3 - tylko w wersji elektronicznej artykułu).

Po 7 tygodniach od rozpoczęcia radioterapii (kilka dni po zakończeniu konwencjonalnego napromieniania i 11 dni po zakończeniu radioterapii przyspieszonej), obserwowano szybkie ustępowanie dolegliwości bólowych i poprawę w przełykaniu. Po upływie dalszych 5-6 tygodni dolegliwości tego typu dotyczyły mniej niż 10\% chorych w obu grupach.

\section{Późne odczyny popromienne}

Analiza późnych odczynów popromiennych wykazała wyższy odsetek teleangiektazji w zakresie skóry u chorych otrzymujących przyspieszoną radioterapię, a różnice były 
znamienne statystycznie. Częstość pozostałych ocenianych późnych działań niepożądanych nie różniła się istotnie w zależności od metody frakcjonowania dawki.

Na rycinach 4-12 (ryciny 4-12 tylko w wersji elektronicznej artykułu) przedstawiono występowanie poszczególnych kategorii odczynów późnych z uwzględnieniem stopnia ich nasilenia zależnie od zastosowanego sposobu frakcjonowania dawki.

W obu grupach chorych będących przedmiotem analizy nie wystąpiły poważne późne powikłania zagrażające życiu lub znacznie obniżające jakość życia, takie jak obrzęk krtani, martwica chrząstek, kości lub uszkodzenie rdzenia kręgowego. Zapalenie chrząstek krtani o niewielkim nasileniu odnotowano u 2 chorych w grupie CF (1\%) i ustąpiło ono po leczeniu zachowawczym. U pojedynczego chorego w grupie CF wystąpiła późna, powierzchniowo ograniczona martwica błony śluzowej, która uległa wygojeniu po leczeniu zachowawczym. Późne zmiany skórne, jak wspomniano powyżej, ujawniały się jako teleangiektazje popromienne, które w stopniu nasilenia 2. lub wyższym wystąpiły u $8 \%$ w grupie CF i u 14\% chorych w grupie AF.

Wszystkie późne odczyny w 2. stopniu nasilenia występowały incydentalnie i ustępowały po leczeniu zachowawczym, nie obniżając jakości życia chorych.

W analizie odczynów późnych zbadano wpływ wielkości objętości napromienianej na ich wystąpienie i stopień nasilenia. Zgodnie z protokołem badania napromienianie dużymi polami dotyczyło wszystkich przypadków raka nadgłośni i stopnia zaawansowania T3 raka głośni. Elektywne napromienianie dużymi polami w pierwszym etapie zakładało podanie dawki 46 Gy, po czym ograniczano objętość wyłącznie do krtani z marginesem i kontynuowano leczenie w ramach drugiego etapu do łącznej dawki $66 \mathrm{~Gy}$.

Założono, że stosowanie dużych pól może wpływać na nasilenie odczynów późnych.

Przeprowadzona analiza statystyczna potwierdziła znamienny wpływ wielkości pól na wystąpienie teleangiektazji $(p=0,02)$ i obrzęku tkanki podskórnej $(p=0,03)$. Odnotowano wystąpienie trendu statystycznego w odniesieniu do zwłóknienia tkanki podskórnej $(p=0,09)$ i ścieńczenia błony śluzowej $(p=0,07)$.

Nie potwierdzono wpływu wielkości pól na częstość i nasilenie pozostałych rodzajów odczynów późnych takich jak zmleczenie błony śluzowej, teleangiektazje błony śluzowej, owrzodzenie i martwica głęboka, dysfagia, suchość w jamie ustnej, obrzęk krtani, zapalenie i marwica chrząstek krtani oraz martwica popromienna kości.

\section{Dyskusja}

Jak wynika z danych pochodzących z dotychczas przeprowadzonych badań klinicznych, zastosowanie przyspieszonego frakcjonowania dawki radioterapii wiąże się ze wzrostem ryzyka wystąpienia nasilonych wczesnych odczy- nów popromiennych. W analizie 33 badań z udziałem łącznie 6181 chorych cechy zapalenia błon śluzowych stwierdzono w 80\% przypadków. Zlewne naloty włóknika (3-4 stopień nasilenia odczynu) obserwowano u 56\% chorych, u których stosowano napromienianie przyspieszone w porównaniu z 34\% u leczonych z użyciem konwencjonalnego frakcjonowania [19].

Overgaard podaje wystąpienie zlewnych nalotów włóknika na błonach śluzowych u 53\% chorych napromienianych frakcjonowaniem przyspieszonym w porównaniu z 33\% $w$ leczeniu konwencjonalnym ( $<<0,0001)$, przy czym odczyn w ramieniu przyspieszonym ustępował po dłuższym czasie. Dane odnośnie występowania i ewolucji odczynu popromiennego błon śluzowych są podobne również w innych opracowaniach $[7,11,20-23]$.

Jeszcze wyższe odsetki chorych z nasilonym odczynem błon śluzowych odnotował Dische w badaniu CHART, w ramach którego stosowano bardzo znaczne skrócenie całkowitego czasu napromieniania przy wykorzystaniu hiperfrakcjonowania dawki. W tej grupie chorych zlewne naloty włóknika obserwowano w 73\% przypadków w porównaniu z 43\% u leczonych konwencjonalnie. Stwierdzono również, że nasilenie odczynów popromiennych w ramieniu przyspieszonym przypadało na trzeci tydzień od momentu rozpoczęcia leczenia, czyli już po zakończeniu radioterapii. W leczeniu konwencjonalnym rozwinięcie się odczynu wczesnego przypadało na 3-6 tydzień leczenia [24]. W większości opracowań odczyn popromienny błon śluzowych jest najczęściej analizowaną wczesną reakcją popromienną. Wyjątek stanowi podsumowanie cytowanego doświadczenia CHART, w którym oceniono narastanie, szczyt i ustępowanie innych reakcji popromiennych, takich jak dysfagia, bóle podczas połykania i stosowanie analgetyków. Szczegółowy jest również opis przebiegu odczynu popromiennego skóry. W przeprowadzonej analizie wczesnych odczynów popromiennych istotne statystycznie różnice wykazano w odniesieniu do bólów przy przełykaniu, stosowania analgetyków i nasilenia rumienia skóry oraz suchego złuszczania. Z pewnością skupienie uwagi na pełnej ocenie toksyczności leczenia było związane z niepowtórzoną w późniejszych badaniach intensywnością napromieniania i koniecznością zapewnienia bezpieczeństwa chorym leczonym najbardziej intensywnym schematem frakcjonowania. Podobnie jak w cytowanych powyżej danych z piśmiennictwa, wystąpienie odczynów obserwowano od trzeciego tygodnia napromieniania, a maksymalne ich nasilenie przypadało na szósty i siódmy tydzień. Wygasanie odczynów następowało po 11-12 tygodniach. Odsetek chorych z bólami przy przełykaniu był w ramieniu przyspieszonym średnio ok. 20\% wyższy w porównaniu z obserwowanym w leczeniu konwencjonalnym, przy czym osiągał najwyższy wskaźnik w 7. tygodniu napromieniania i wynosił $67 \%$ w grupie AF oraz 32\% w grupie CF. 
Dysfagię obserwowano średnio o 10\% częściej, a odsetek chorych z nasilonymi trudnościami podczas przełykania w 6 tygodniu napromieniania był wyższy o 20\% w ramieniu przyspieszonym w porównaniu z konwencjonalnym.

Występowanie odczynu na błonach śluzowych stwierdzono średnio ok. o 20\% częściej u chorych napromienianych sposobem przyspieszonym, a w 6 tygodniu leczenia odsetek chorych z rozlaną epitheliolizą błon śluzowych był o $25 \%$ wyższy w grupie AF w porównaniu z CF.

Nasilenie odczynów wczesnych było znamiennie większe u chorych napromienianych schematem przyspieszonego frakcjonowania w porównaniu z leczonymi konwencjonalnie, jednak analizując łączną liczbę przypadków, w których odczyn popromienny osiągnął nasilenie $\geq 2^{\circ}$, nie stwierdzono różnic pomiędzy grupami AF i CF (79\% vs 73\%).

Istotną informacją wynikającą z analizy danych pochodzących z wieloletniej obserwacji jest udowodnienie, że skrócenie o jeden tydzień całkowitego czasu leczenia w wyniku zastosowania przyspieszonego frakcjonowania nie miało wpływu na nasilenie toksyczności późnej w porównaniu z napromienianiem konwencjonalnym. Obserwacje te potwierdzają dane innych autorów [7, 12, 25, 26].

Zjawisko to wskazuje, że zastosowany w ramieniu doświadczalnym badania KBN 0925 przyspieszony schemat frakcjonowania stanowi optymalny wariant, w którym zachowane są proporcje pomiędzy poprawą wyników leczenia i ryzykiem wystąpienia odczynów późnych.

Wysokie prawdopodobieństwo wyleczenia napromienianiem chorych na raka krtani, wiążące się z koniecznością zapewnienia długoterminowego bezpieczeństwa i adekwatnej jakości życia, czyni kluczowym zagadnienie późnych odczynów popromiennych. Nasilenie odczynów późnych jest nierozerwalnie związane zarówno z wysokością dawki frakcyjnej, jak i intensywnością frakcjonowania. Wyższa dawka frakcyjna wiąże się z ryzykiem nieodwracalnych powikłań późnych. Bezpieczne stosowanie radioterapii wymaga dużej ostrożności, ponieważ w przypadku wystąpienia późnego odczynu promiennego nie istnieją możliwości skutecznego leczenia zachowawczego. Wiele badań, w tym również to przedstawiane, jednoznacznie sugeruje, że coraz szersze stosowanie bardziej agresywnych, alternatywnych schematów frakcjonowania jest z punktu widzenia ryzyka odczynów późnych bezpieczne, a ograniczenia metody wynikają z nasilenia toksyczności wczesnej. Jednak należy brać pod uwagę fakt, że wybitnie nasilona intensywność wczesnego odczynu popromiennego może być skorelowana z możliwością stosunkowo szybkiego wystąpienia nieakceptowalnej toksyczności późnej, jak wykazano w niektórych opracowaniach $[8,11]$. W przedstawianej pracy obserwowano jedynie znamiennie wyższy odsetek występowania teleangiektazji skóry u chorych leczonych frakcjonowaniem przyspieszonym. Tego typu reakcja późna nie ma jednak istotnie negatywnego wpływu na długoterminową jakość życia chorych.
W zakresie nasilenia pozostałych analizowanych odczynów późnych nie stwierdzono znamiennych różnic pomiędzy frakcjonowaniem przyspieszonym a konwencjonalnym. Zjawisko to przesądza o możliwości bezpiecznego stosowania przyspieszonego frakcjonowania dawki radioterapii u chorych na raka krtani w stopniu zaawansowania T1-3N0.

\section{Wnioski}

Skrócenie czasu leczenia o 7 dni w porównaniu ze schematem konwencjonalnego frakcjonowania u chorych na wczesnego raka krtani pozwala na poprawę wyleczalności miejscowej o 14-15\%.

Przyspieszone napromienianie nie wpływa w istotny sposób na przebieg leczenia, chociaż toksyczność wczesna radioterapii jest większa w porównaniu z leczeniem konwencjonalnym.

Nie odnotowano poważnych późnych powikłań popromiennych wśród chorych leczonych w sposób przyspieszony ani u poddanych radioterapii konwencjonalnej, co przesądza o możliwości bezpiecznego stosowania frakcjonowania przyspieszonego u chorych na wczesnego raka krtani.

\section{Dr hab. n. med. Zbigniew Szutkowski}

Zakład Teleradioterapii

Centrum Onkologii - Instytut

im. Marii Skłodowskiej-Curie

ul. W.K. Roentgena 5, 02-781 Warszawa

e-mail:zszutkowski@coi.waw.pl

Otrzymano: 3 października $2013 \mathrm{r}$.

Przyjęto do druku: 11 lutego 2014 r.

\section{Piśmiennictwo}

1. Withers HR, Maciejewski B, Taylor JM i wsp. Accelerated repopulation in head and neck cancer. Front Radiat Ther Oncol 1988; 22: 105-110.

2. Maciejewski B, Withers HR, Taylor JM i wsp. Dose fractionation and regeneration in radiotherapy for cancer of the oral cavity and oropharynx: tumor dose-response and repopulation. Int J Radiat Oncol Biol Phys 1989; 16: 831-843.

3. Trott KR. Cell repopulation and overall treatment time. Int J Radiat Oncol Biol Phys 1990; 19: 1071-1075.

4. Cox JD, PajakTF, Marcial VA i wsp. ASTRO plenary: interfraction interval is a major determinant of late effects, with hyperfractionated radiation therapy of carcinomas of upper respiratory and digestive tracts: results from Radiation Therapy Oncology Group protocol 8313. Int J Radiat Oncol Biol Phys 1991; 20: 1191-1195.

5. Cox JD, PajakTF, Marcial VA i wsp. Dose-response for local control with hyperfractionated radiation therapy in advanced carcinomas of the upper aerodigestive tracts: preliminary report of radiation therapy oncology group protocol 83-13. Int J Radiat Oncol Biol Phys 1990; 18: 515-521.

6. Horiot JC, Bontemps $\mathrm{P}$, van den Bogaert W i wsp. Accelerated fractionation (AF) compared to conventional (CF) improves loco-regional control in the radiotherapy of advanced head and neck cancers: results of the EORTC 22851 randomized trial. Radiother Oncol 1997; 44: 111-121.

7. Fu KK, Pajak TF, Trotti A i wsp. A Radiation Therapy Oncology Group (RTOG) phase III randomized study to compare hyperfractionation and two variants of accelerated fractionation to standard fractionation radiotherapy for head and neck squamous cell carcinomas: first report of RTOG 9003. Int J Radiat Oncol Biol Phys 2000; 48: 7-16.

8. Jackson SM, Weir LM, Hay JH i wsp. A randomized trial of accelerated versus conventional radiotherapy in head and neck cancer. Radiother Oncol. 1997; 43: 39-46.

9. Overgaard J, Sand Hansen H, Specht L i wsp. Five compared with six fractions per week of conventional radiotherapy of squamous-cell 
carcinoma of head and neck: DAHANCA $6 \& 7$ randomized controlled trial. Lancet 2003; 362: 933-940.

10. Olmi P, Crispino S, Fallai C i wsp. Locoregionally advanced carcinoma of the oropharynx: conventional radiotherapy versus accelerated hyperfractionated radiotherapy versus concomitant radiotherapy and chemotherapy - a multicenter randomized trial. Int J Radiat Oncol Biol Phys 2003; 55: 78-92.

11. Składowski K, Maciejewski B, Goleń M i wsp. Randomized clinical trial on 7-day-continuous accelerated irradiation (CAIR) of head and neck cancer - report on 3-year tumor control and normal tissue toxicity. Radiother Oncol 2000; 55: 101-110.

12. Hliniak A, Gwiazdowska B, Szutkowski Z i wsp. A multicentre randomized/controlled clinical trial of conventional versus modestly accelerated radiotherapy in laryngeal cancer: influence of a 1 week shortening overall time. Radiother Oncol 2002; 62: 1-10.

13. Bourhis J, Lapeyre M, Tortochaux J i wsp. Phase III randomized trial of very accelerated radiation therapy compared with conventional radiation therapy in squamous cell head and neck cancer: a GORTEC trial. J Clin Oncol 2006; 24: 2873-2878.

14. Bourhis J, Syz N, Overgaard KK i wsp. Convetional versus modified fractionated radiotherapy; meta-analysis of radiotherapy in head and neck squamous cell carcinoma: a meta-analysis based on individual patients data. Int J Radiat Oncol Biol Phys 2002; 54 (Suppl): 71-72.

15. Bourhis J, Overgaard J, Audry H i wsp. Hyperfractionated or accelerated radiotherapy in head and neck cancer: a meta-analysis. Lancet 2006; 368: 843-854.

16. ICRU Report 50, Prescribing, Recording and Reporting Photon Beam Therapy. 1991.

17. Szutkowski Z. Zbadanie skuteczności przyspieszonej radioterapii u chorych na raka górnego i środkowego piętra krtani w stopniu T1-3N0. Rozprawa habilitacyjna. Nowotwory J Oncol 2010; 60 supl. 3.
18. Dische S. The uniform reporting of treatment-related morbidity. Semin Radiat Oncol 1994; 4: 112-118.

19. Trotti A, Bellm LA, Epstein JB i wsp. Mucositis incidence, severity and associated outcomes in patients with head and neck cancer receiving radiotherapy with or without chemotherapy: a systematic literature review. Radiother Oncol 2003; 66: 253-262.

20. Bentzen J.K.D., Hansen H.S. Primary radiotherapy of carcinoma of the supraglottic larynx-a multivariate analysis of prognostic factors. Int J Radiat Oncol Biol Phys 1998; 41: 355-360.

21. Cellai E, Frata P, Magrini SM i wsp. Radical radiotherapy for early glottic cancer: results in a series of 1087 patients from two Italian radiation oncology centers. I. The case of T1N0 disease. Int J Radiat Oncol Biol Phys 2005; 63; 1378-1386.

22. Garden AS, Morrison WH, Ang KK i wsp. Hyperfractionated radiation in the treatment of squamous cell carinomas of the head and neck: a comparison of two fractionation schedules. Int J Radiat Oncol Biol Phys 1995; 31: 493-502.

23. Yamazaki H, Nishiyama K, Tanaka E i wsp. Radiotherapy for early glottic carcinoma (T1NOM0): results of prospective randomized study of radiation fraction size and overall treatment time. Int J Radiat Oncol Biol Phys 2006; 64: 77-82.

24. Dische $S$, Saunders M, Barrett A i wsp. A randomised multicentre trial of CHART versus conventional radiotherapy in head and neck cancer. Radiother Oncol 1997; 44: 123-136.

25. Fu KK, Clery M, Ang KK i wsp. Randomized phase I/II trial of two variants of accelerated fractionated radiotherapy regimens for advanced head and neck cancer: results of RTOG 88-09. Int J Radiat Oncol Biol Phys 1995; 32: 589-597.

26. Cummings BJ, O'Sullivan B, Keane T i wsp. Larynx conservation in a randomized trial of hyperfactionated (HFRT) versus conventional once daily radiation (CRT): A subgroup analysis. EurJ Cancer 1997; 33 (suppl 8): S254. 


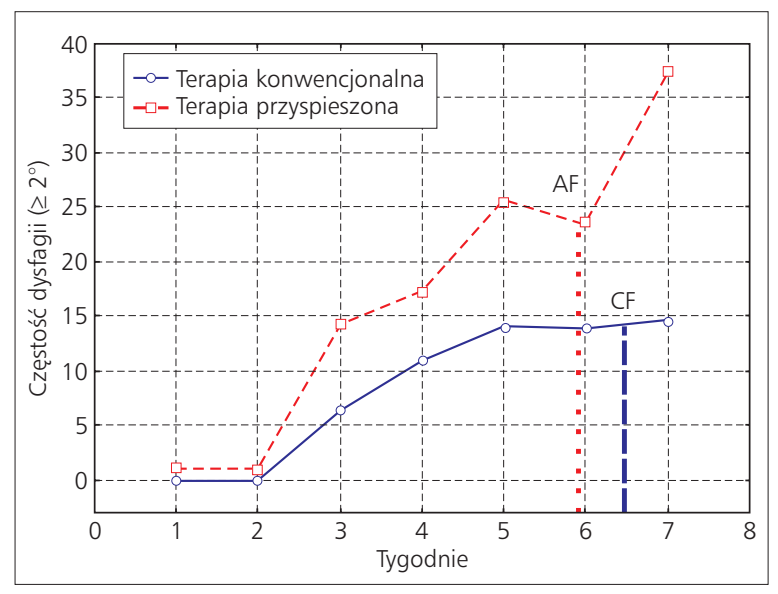

Rycina 2. Częstość nasilonych trudności w przełykaniu (dysfagia $\geq 2^{\circ}$ ) w zależności od frakcjonowania dawki napromieniania; AF vs CF (linie pionowe oznaczają czas zakończenia radioterapii w grupie AF i CF)

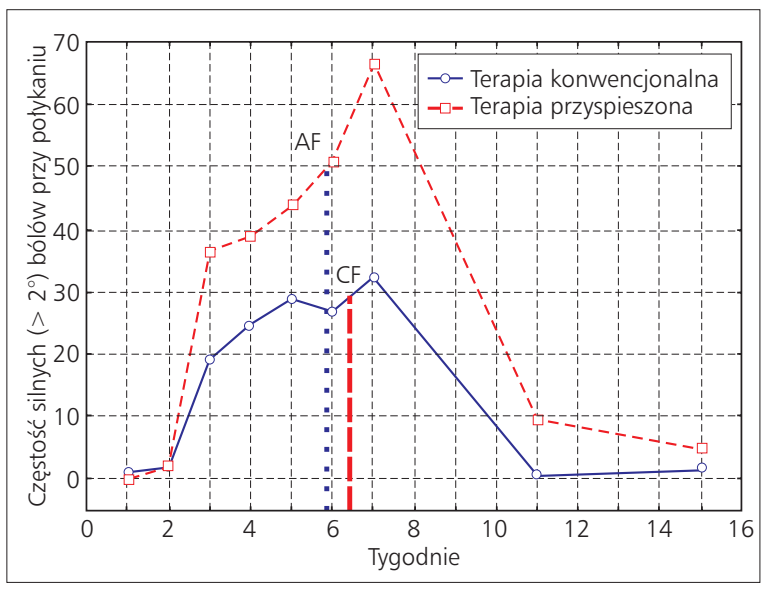

Rycina 3. Częstość występowania silnych ( $\left.\geq 2^{\circ}\right)$ bólów przy przełykaniu w zależności od frakcjonowania dawki napromieniania (linie pionowe oznaczają czas zakończenia radioterapii w grupie AF i CF)

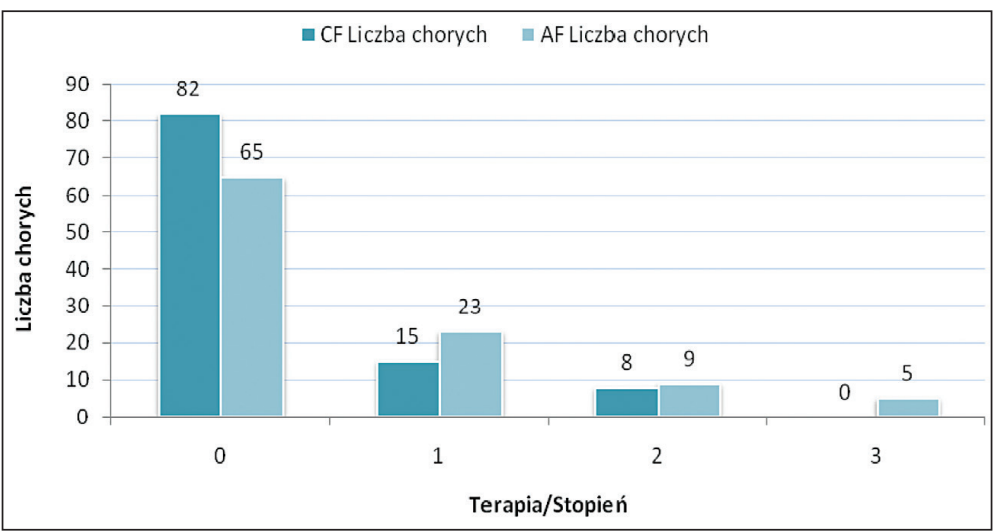

Rycina 4. Teleangiektazje skóry. Brak danych lub nie oceniano - 10 chorych. Potwierdzono znamiennie częstsze występowanie teleangiektazji i wyższe stopnie ich nasilenia u chorych leczonych metodą frakcjonowania przyspieszonego $(p=0,03)$

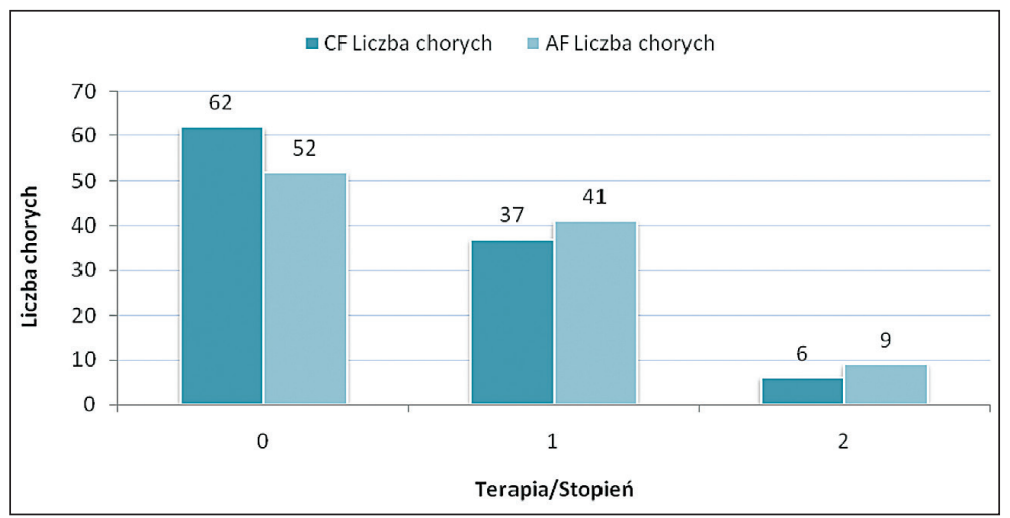

Rycina 5. Obrzęk tkanki podskórnej. Brak danych lub nie oceniano - 10 chorych. Nie wykazano znamiennych statystycznie różnic w zakresie częstości i nasilenia obrzęku tkanki podskórnej zależnie od schematu frakcjonowania 


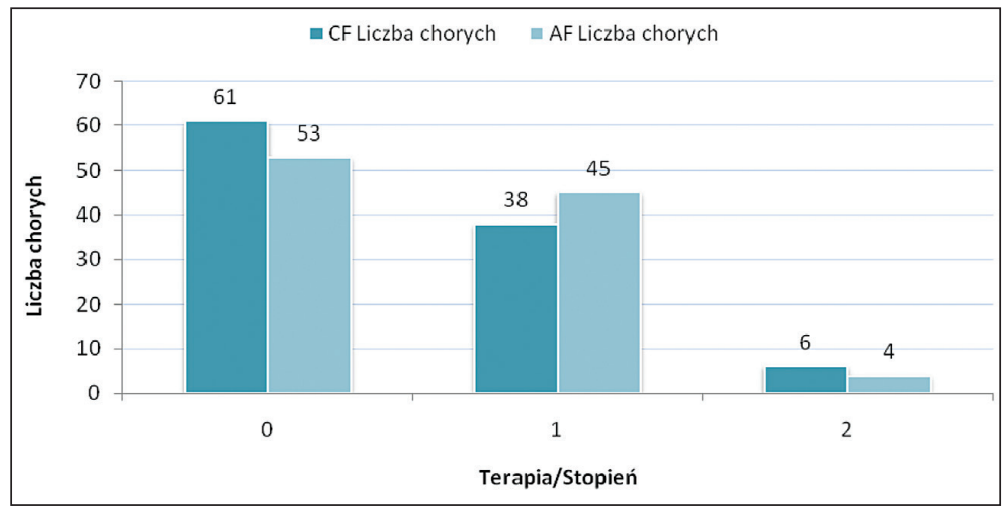

Rycina 6. Zwłóknienie tkanki podskórnej. Brak danych lub nie oceniano - 10 chorych. Nie wykazano znamiennych statystycznie różnic w zakresie częstości i nasilenia zwłóknienia tkanki podskórnej zależnie od schematu frakcjonowania

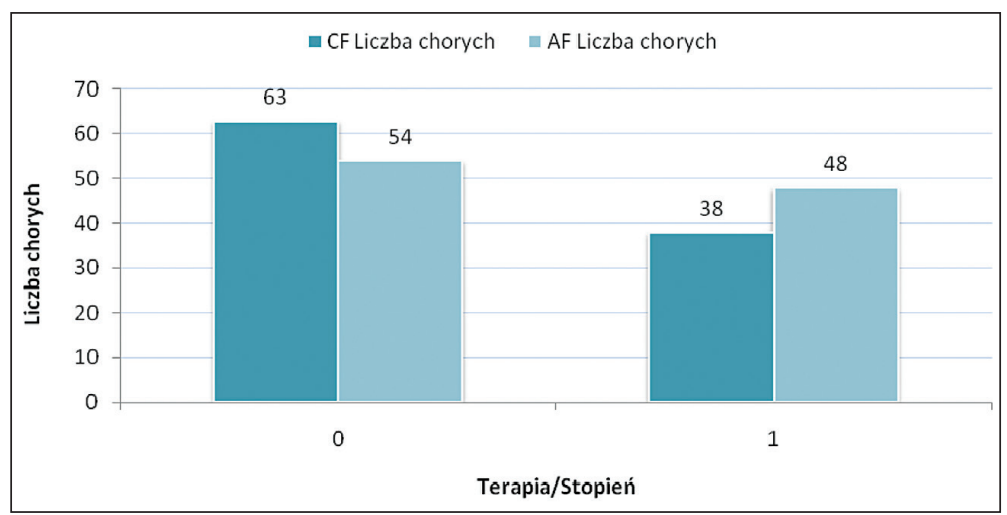

Rycina 7. Ścieńczenie błony śluzowej. Brak danych lub nie oceniano - 14 chorych. Nie wykazano znamiennych statystycznie różnic w zakresie częstości i nasilenia ścieńczenia błony śluzowej zależnie od schematu frakcjonowania

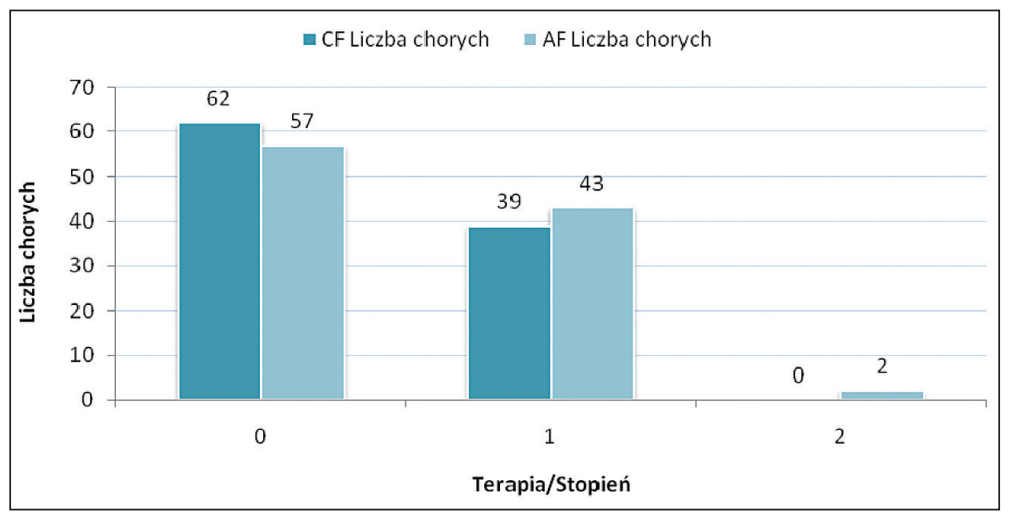

Rycina 8. Zmleczenie błony śluzowej. Brak danych lub nie oceniano - 14 chorych. Nie wykazano znamiennych statystycznie różnic w zakresie częstości i nasilenia zmleczenia błony śluzowej zależnie od schematu frakcjonowania 


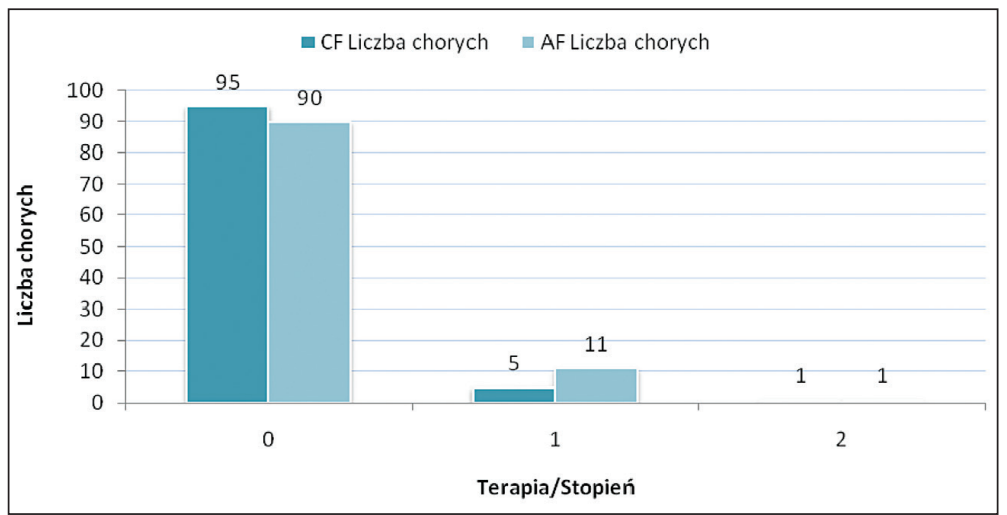

Rycina 9. Teleangiektazje błony śluzowej. Brak danych lub nie oceniano - 14 chorych. Nie wykazano znamienności statystycznej w badanych schematach frakcjonowania

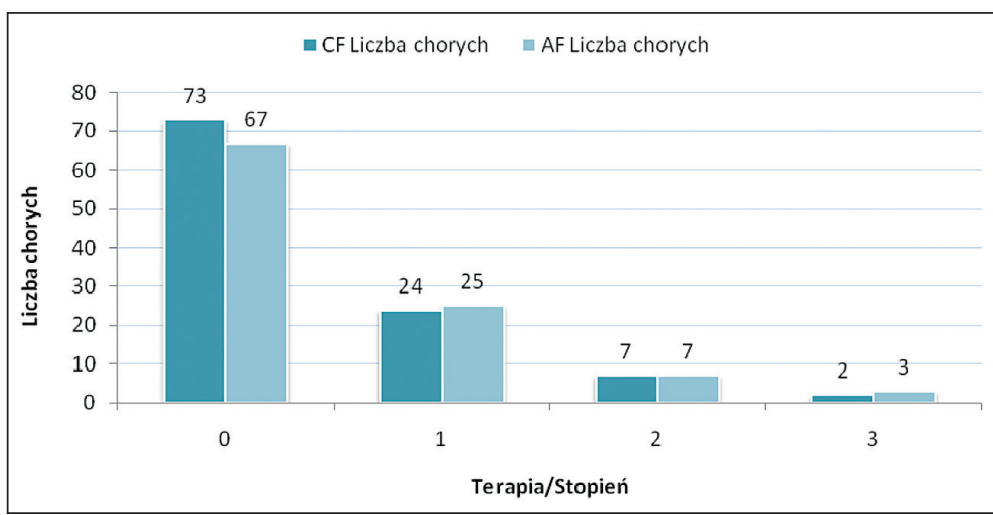

Rycina 10. Dysfagia. Brak danych lub nie oceniano - 9 chorych. Nie wykazano znamienności statystycznej w badanych schematach frakcjonowania

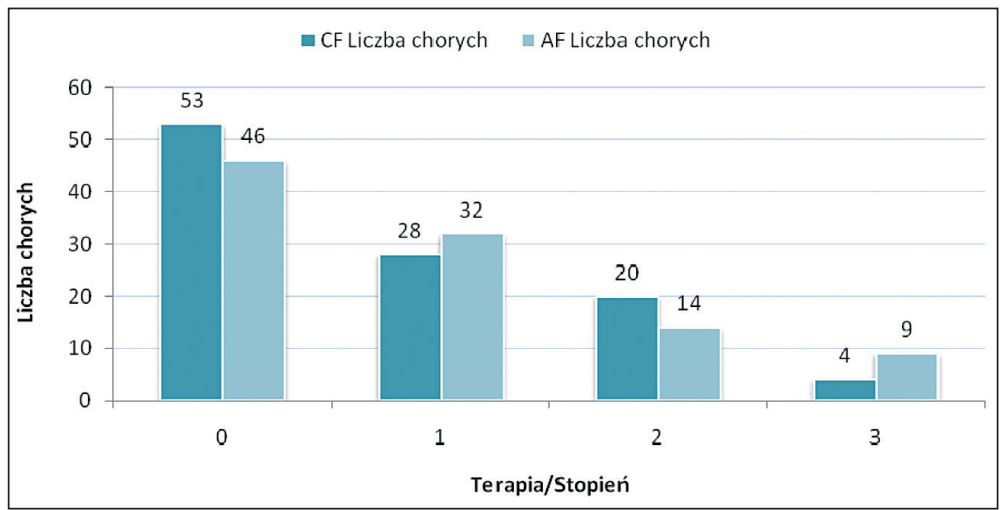

Rycina 11. Suchość w jamie ustnej. Brak danych lub nie oceniano - 11 chorych. Nie wykazano znamienności statystycznej w badanych schematach frakcjonowania 


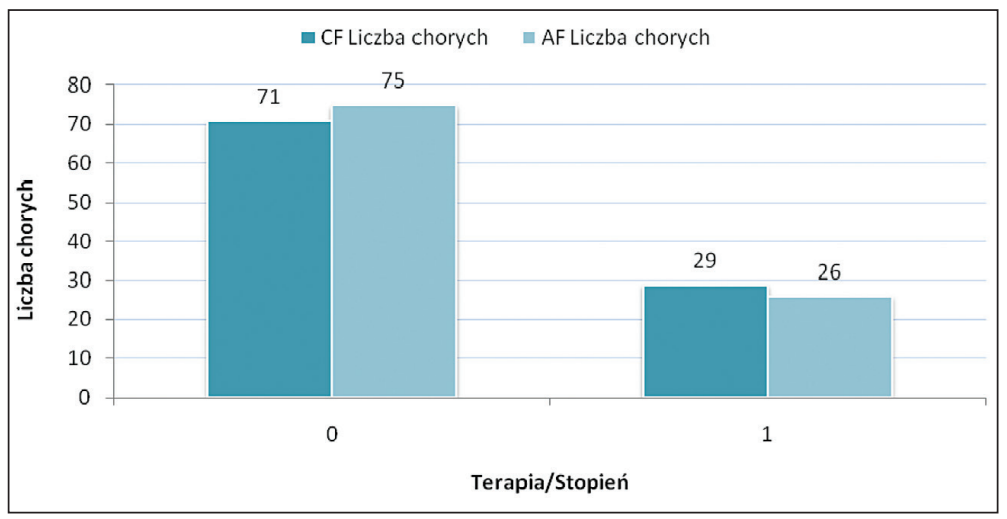

Rycina 12. Obrzęk krtani. Brak danych lub nie oceniano - 16 chorych. Nie wykazano znamienności statystycznej w badanych schematach frakcjonowania 